\title{
PRAXELIS CLEMATIDEA (ASTERACEAE,EUPATORIEAE,PRAXELINAE) IN URUGUAY: FIRST RECORD OF THE GENUS AND THE SPECIES
}

\author{
Vanina G. Salgado', Mariana A. Grossi' ${ }^{2,3}$, H. Andrés González ${ }^{4}$ \& Diego G. Gutiérrez ${ }^{1,3}$
}

\begin{abstract}
${ }^{1}$ División Plantas Vasculares, Museo Argentino de Ciencias Naturales (MACN-CONICET), Av. Ángel Gallardo 470, C1405DJR Ciudad de Buenos Aires, Argentina; vgsalgado@macn.gov.ar (author for correspondence).

${ }^{2}$ División Plantas Vasculares, Museo de La Plata (Facultad de Ciencias Naturales y Museo, Universidad Nacional de La Plata), Paseo del Bosque s.n., B1900FWA La Plata, Buenos Aires, Argentina.

${ }^{3}$ Laboratorio de Morfología Comparada de Espermatofitas, Facultad de Ciencias Agrarias y Forestales, Universidad Nacional de La Plata, Av. 60 s.n. entre 116 y 118, B1900FWA La Plata, Buenos Aires, Argentina.

${ }^{4}$ Departamento de Botánica, Museo Nacional de Historia Natural, 25 de mayo 582, CP 11000, Montevideo, Uruguay.
\end{abstract}

\begin{abstract}
Salgado, V. G.; M. A. Grossi, H. A. González \& D. G. Gutiérrez. 2020. Praxelis clematidea (Asteraceae, Eupatorieae, Praxelinae) in Uruguay: first record of the genus and the species. Darwiniana, nueva serie 8(2): 479-489.

During the revision of the southern South American species of Praxelis, populations of $P$. clematidea were found in northwestern Uruguay. In this study, we provide the first record of the genus and the species for the Uruguayan flora, along with taxonomic and morphological analyses based on herbarium specimens and field observations. In addition, uses of P. clematidea, its distribution and habitat, common names, an illustration and a key to differentiate the species of Praxelis of Uruguay and surrounding areas of Argentina and Brazil are presented.
\end{abstract}

Keywords. Argentina; Brazil; morphology; taxonomy; weed.

Resumen. Salgado, V. G.; M. A. Grossi, H. A. González \& D. G. Gutiérrez. 2020. Praxelis clematidea (Asteraceae, Eupatorieae, Praxelinae) en Uruguay: primer registro del género y la especie. Darwiniana, nueva serie 8(2): 479-489.

Durante la revisión de las especies del género Praxelis de Sudamérica meridional, poblaciones de P. clematidea fueron halladas en el noroeste de Uruguay. En este trabajo proporcionamos el primer registro del género y la especie para la flora Uruguaya junto con un análisis taxonómico y morfológico basado en ejemplares de herbario y observaciones de campo. Además, se presentan los usos de $P$. clematidea, su distribución y hábitat, nombres comunes, una ilustración y una clave para diferenciar las especies de Praxelis de Uruguay y áreas circundantes de Argentina y Brasil.

Palabras clave. Argentina; Brasil; maleza; morfología; taxonomía.

\section{INTRODUCTION}

The tribe Eupatorieae (Asteraceae) includes almost 190 genera and 2200-2500 species with a predominantly Neotropical distribution. Species richness is particularly high in Brazil, tropical Andes and Mexico (King \& Robinson, 1987; Hind \& Robinson, 2007; Panero \& Crozier, 2016; Rivera et al., 2016a; Roque et al., 2017; Gonzáles et al., 2018, Grossi et al., 2020). According to the most recent phylogeny (Rivera et al., 2016b), Eupatorieae have several evolutionary lineages that are taxonomically classified in 20 subtribes, among them Praxelinae with approximately 190 species grouped in seven genera: Chromolaena DC., Eitenia R.M. King \& H. Rob., Eupatoriopsis Hieron., Lomatozona Baker, Osmiopsis R.M. 
King \& H. Rob., Praxeliopsis G.M. Barroso, and Praxelis Cass. (King \& Robinson, 1987; Hind \& Robinson, 2007). This subtribe inhabits from southern North America up to central Argentina and Uruguay. Chromolaena and Praxelis are the southernmost genera, reaching the mountain ranges of the Pampas region (Cabrera, 1941; 1963; Cabrera et al., 1999; Freire \& Ariza Espinar, 2014). Species of these genera were, throughout most of the history of the Eupatorieae, classified totally or partially into the large genus Eupatorium L. (Candolle, 1836; Baker, 1876; Robinson, 1923; Cabrera \& Vittet, 1954). As a result of a series of studies published in the 1970s and 1980s, this genus was split into ca. 100 genera, which were described as new, raised from infrageneric groups or reinstalled to genus level (King \& Robinson, 1987). This taxonomical point of view was completely accepted for the southern South America floras in the early twenty-first century (Troncoso Oliveira, 2010; Freire \& Ariza Espinar, 2014).

The South American genus Praxelis, with 19 species, is one of the most widely distributed of the subtribe, ranging from Colombia, Venezuela and the Guianas up to central Argentina and southernmost Brazil (Dillon \& Hensold, 1993; Badillo, 2001; Funk et al., 2007; Freire \& Ariza Espinar, 2014; Abreu \& Esteves, 2017; Ávila et al., 2016; Bernal et al., 2019; Christ \& Ritter, 2019). It has not been recorded to this day in Chile, Ecuador, or Uruguay. It is defined by its pappus with numerous scabrid bristles, deciduous phyllaries, capitula with conical receptacles and asymmetrical carpopodium. These structures have been recognized as important evolutionary characters in Eupatorieae (Robinson et al., 2009; Grossi et al., 2020).

Knowledge about the flora of southern South America varies according to the country or taxonomic group considered. In the case of Uruguay, several efforts have been made in recent years to catalogue the biodiversity of Asteraceae (Sancho et al., 2006; Hurrell, 2013; Trujillo et al., 2014; Valtierra \& Bonifacino, 2014) and particularly of Eupatorieae (Pérez Sobrino, 2016; Rodríguez-Cravero et al., 2017; 2019). Currently, Praxelinae is represented in Uruguay by six species of Chromolaena: C. caaguazuensis (Hieron.) R.M. King \& H. Rob., C. hirsuta (Hook. \& Arn.) R.M. King \& H. Rob., C. ivifolia (L.) R.M. King \& H. Rob, C. laevigata (Lam.) R.M. King \& H. Rob., C. squarrulosa (Hook. \& Arn.) R.M. King \& H. Rob., and C. verbenacea (DC.) R.M. King \& H. Rob. (Freire, 2008; Flora del Cono Sur, 2020). During the revision of species of Praxelis in southern South America, populations of $P$. clematidea R.M. King \& H. Rob. were recorded in Uruguay. The goals of this work are to report the genus and the species for the Uruguayan flora for the first time and to establish its differences with morphologically similar species within Praxelinae in Uruguay and surrounding areas of Argentina and Brazil.

\section{MATERIAL AND METHODS}

We analyzed specimens and photographs from the following herbaria: BA, BAA, CORD, ECT, LIL, LP, MBM, MVJB, MVFA, MVM, and SI (Thiers, 2020). Descriptions are based on herbarium specimens and field observations. Several field trips were made throughout Uruguay and eastern and northeastern Argentina, during the years 2017, 2019, and 2020. Specimens collected were deposited in BA, LP, MVFA and/or MVM.

A detailed analysis of the species was carried out considering macro and micromorphological characters, especially those previously used for delimiting genera of Praxelinae and species of Praxelis: leaf, involucre, phyllary, cypsela, pappus, and trichomes (King \& Robinson, 1987; Grossi et al., 2020). Leaves and capitula were rehydrated, treated with a clearing process and stained with 2\% safranin (Zarlavsky, 2014). Samples were examined with a Nikon Eclipse E200 microscope. For scanning electron microscopy (SEM) studies, dry materials (cypsela, pappus and receptacle) were placed directly on the stubs, coated with palladium/ gold, and observed in a Philips XL-30SEM at the Argentinian Museum of Natural Sciences.

The species was illustrated by M. Alejandra Migoya (FCAyF, UNLP), with sketches of the capitulum and phyllaries made by Diego G. Gutiérrez. 


\section{RESULTS}

Praxelis clematidea R.M. King \& H. Rob., Phytologia 20: 194. 1970. Eupatorium urticifolium L. f. var. clematideum Hieron. ex Kuntze, Revis. Gen. Pl. 3: 148. 1898, nom. illeg. Eupatorium urticifolium L. f. var. clematideum Chodat, Bull. Herb. Boissier 2: 711. 1903, nom. illeg. Eupatorium catarium Veldkamp, Gard. Bull. Singapore 51: 121. 1999, nov. nom. Eupatorium clematideum Griseb., Abh. Königl. Ges. Wiss. Göttingen 19: 172. 1879, nom. illeg., not (Wall. ex DC.) Sch. Bip. TYPE: Argentina, Córdoba, "pr. Córdoba", P. G. Lorentz 81 (lectotype GOET 0001494 [photo!], designated by Freire \& Ariza Espinar, Flora Argentina 7 (1): 404. 2014); isolectotype GOET 001493 [photo!]). Figs. 1 and 2.

Annual or perennial herbs, or rarely subshrubs, somewhat woody at base, up to $0.5-1 \mathrm{~m}$ tall. Stems erect or ascendant, generally laxly foliose, cylindrical, striated hirsute, rarely glabrescent. Leaves opposite, petiolate, petioles up to $2 \mathrm{~cm}$ long, hirsute; leaf blades 2-7 x 1-5 cm, ovate or ovaterhombic, apex acute, basis attenuate or cuneate, margins serrate, membranous, adaxial surfaces hirsute with uniseriate simple hairs, abaxial surfaces densely hirsute with uniseriate simple hairs and glandular hairs; actinodromous. Capitulescence of densely many-headed corymbiform cymes. Capitula subsessile, very short peduncles up to $0.7 \mathrm{~cm}$ long, hirsute with uniseriate simple hairs. Involucres 5.5$9 \times 3.5-9 \mathrm{~mm}$, campanulate, phyllaries imbricate $18-24$, in 3-5 series, increasing gradually in length, outers 3.6-9 x 0.4-2 mm, ovate, apices strongly acuminate, margins entire, pubescent mainly at the apex, inners 5-8 x 0.8-2 mm, narrowly oblong, apices acute or acuminate, sometimes attenuate, margins entire, glabrescent, all 3-5-nerved dorsally and deciduous. Receptacles highly conical, glabrous. Florets 30-50, bisexual, corollas 3-4.5 x $0.4-0.7 \mathrm{~mm}$, tubular-funnelform, lilac, whitish at maturity, shortly 5-lobed, lobes $0.3-0.7 \mathrm{~mm}$ long, glandular or eglandular, papillose on inner surface; styles 4-7.5 mm long, basis not enlarged, glabrous, style branches 1.5-4 $\mathrm{mm}$ long, linear, densely long-papillose; stamens with anther apical appendages ovate, collars balusterform, basis rounded.
Cypselae 1.7-2.4 x $0.4-0.8 \mathrm{~mm}$, obovate, obcompressed, 2-4-ribbed, setuliferous mainly on the ribs, carpopodium distinct, asymmetrical, laterally inserted in the receptacle. Pappus of 1630 bristles, 2-4 mm long, scabrid persistent white.

Common names. Two common names have been reported in Argentina: "carapari” (Novara, 2009) and "langosta" (English locust; Cantero et al., 2019) but they seem to be scarcely used. In China, it is known as 假臭草: Jia Chou Cao (eFloras, 2020).

Distribution and habitat. Praxelis clematidea (Figs. 1 and 2) is a widely spread native species in South America inhabiting Argentina, Bolivia, Brazil, Paraguay, and Peru (Dillon \& Hensold, 1993; Cabrera et al., 1996; Freire, 2008; Troncoso Oliveira, 2010; Robinson, 2014; Abreu, 2015; Ávila et al., 2016), reaching with this new record northwestern Uruguay, in the departments of Artigas and Salto (Fig. 3). It occurs in subtropical forests and rainforests, shrublands and grasslands. In Uruguay, it is found on roadsides as a ruderal plant (Fig. 2B) in the Cuenca Sedimentaria del Oeste ecoregion (Brazeiro, 2015). In its native range, $P$. clematidea is commonly found on roadsides and as a weed in cultivated areas (Marzocca, 1976; De Egea et al., 2016).

Observations. Within Praxelinae, Chromolaena and Praxelis are the two southernmost distributed genera of the subtribe. They share several morphological characters like numerous bristles of pappus with long equal or subequal elements and cypselae with usually more than two ribs (Fig. 4 A-B). However, Praxelis is morphologically well circumscribed by its 3-5-seriate and campanulate involucre, highly conical receptacles and cypselae with asymmetrical carpopodium laterally inserted to the receptacle (Fig. 4 C-D).

Praxelis clematidea is a plant of ethnobotanical interest (Barboza et al., 2006) with antibacterial effect against both Gram + and Gram - bacteria, antimycotic effect (Filho et al., 2013; 2016; Li et al., 2017), anti-neuroinflammatory agent (Xiao et al., 2020) and significant gastroprotective activity (Falcão et al., 2013). Other possible applications include phytoremediation (Fu et al., 2017; Wei et al., 2018). 


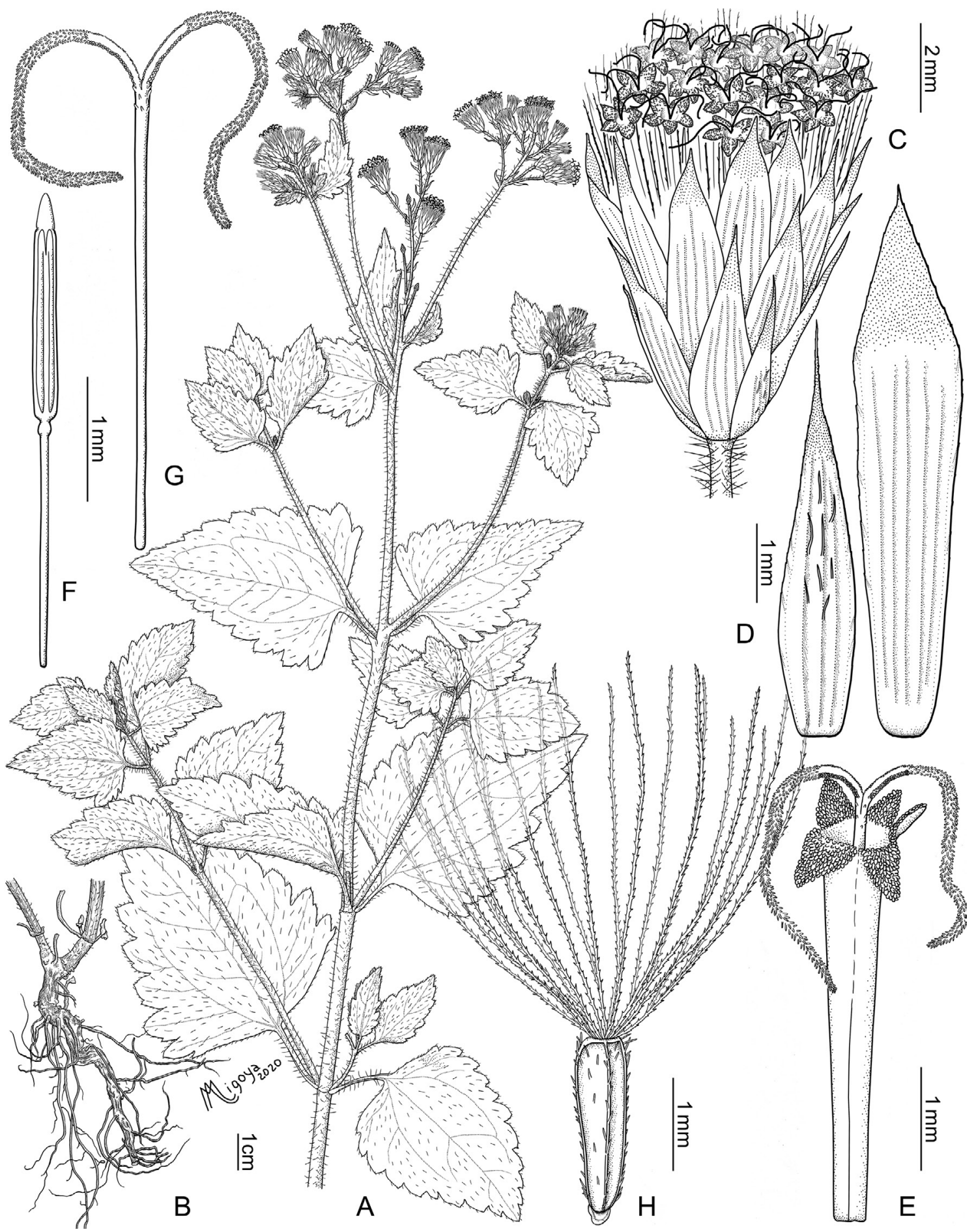

Fig. 1. Praxelis clematidea. A, plant. B, detail of basal stems and roots. C, capitulum. D, phyllaries (outer on the left, inner on the right). E, floret without cypsela and pappus. F, stamen. G, style. H, cypsela with pappus. Illustration: A. Migoya. Material from Gutiérrez 1707 (BA). 

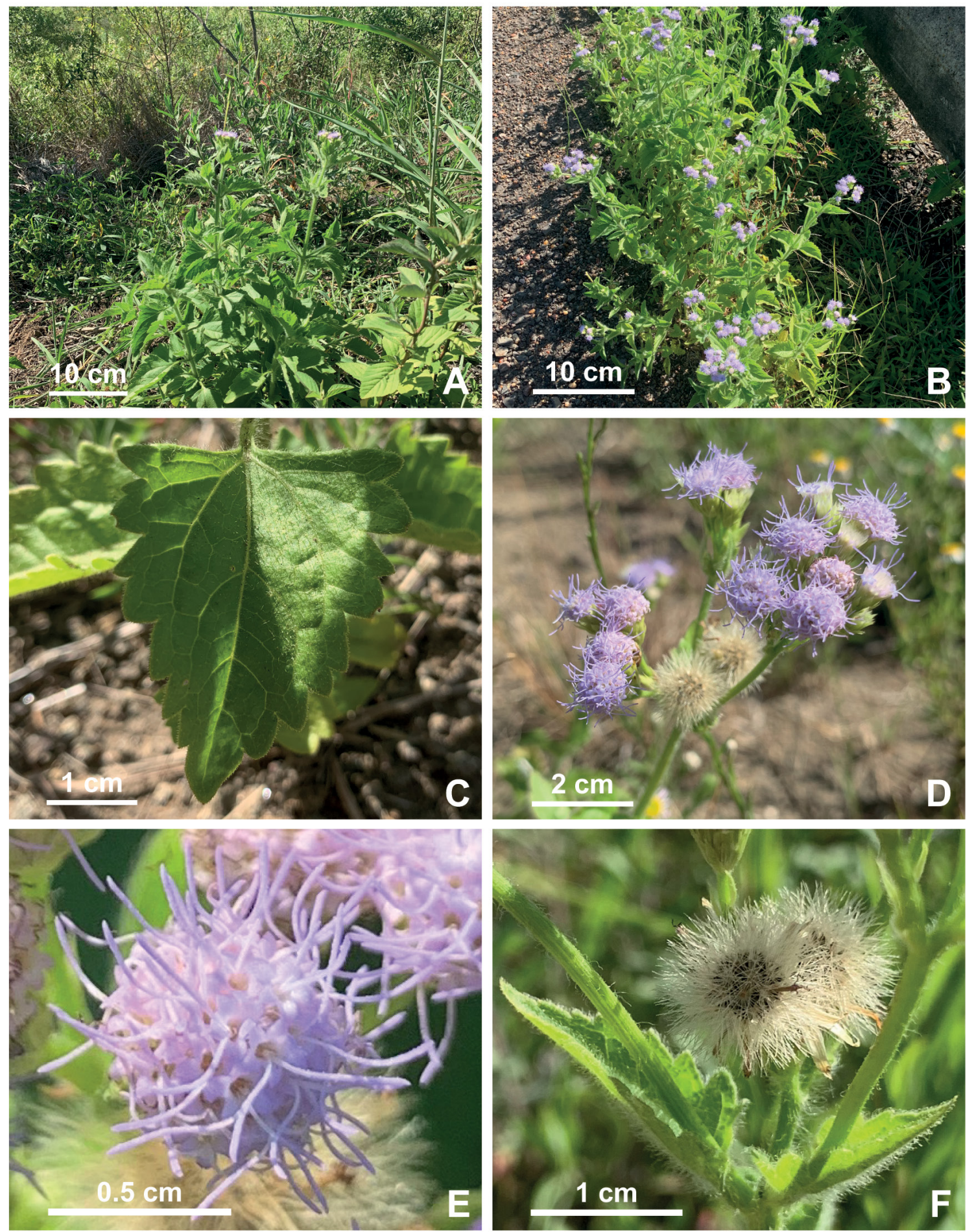

Fig. 2. Praxelis clematidea. A, plant in its habitat. B, population. C, leaf. D, capitulescence. E, capitulum in superficial view. F, mature capitula showing the pappus. Photos by V. G. Salgado and D. G. Gutiérrez. Color version at http://www. ojs.darwin.edu.ar/index.php/darwiniana/article/view/912/1193 


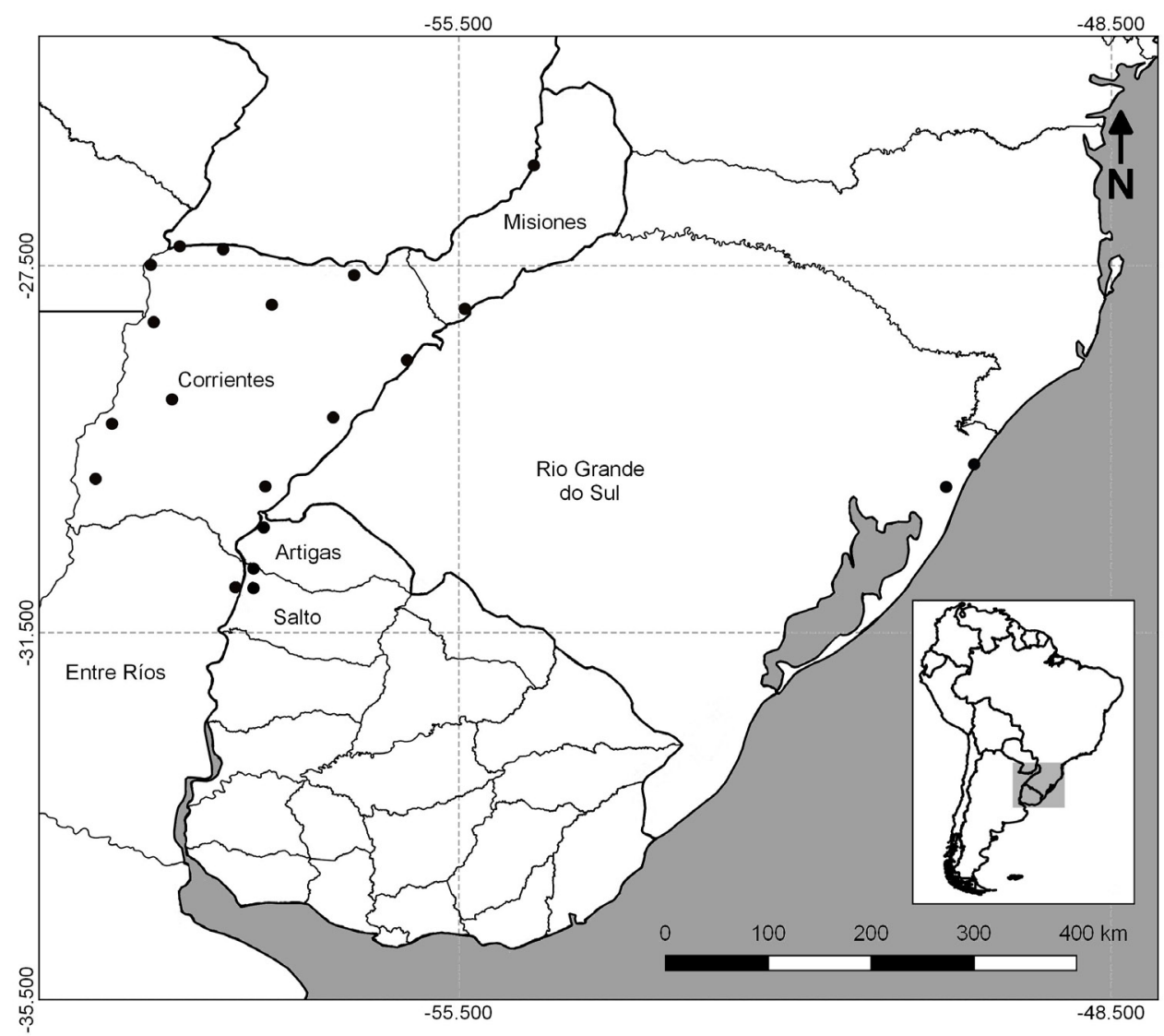

Fig. 3. Distribution of Praxelis clematidea in Uruguay and surrounding areas of Argentina and Brazil.

\section{Specimens examined}

ARGENTINA. Corrientes. Depto. Empedrado, Ruta Nacional 12 y río San Lorenzo, 27-III-1976, Schinini 12833 (SI). Depto. General Paz, General Paz, I-1966, Krapovickas 11830 (LP). Depto. Goya, 28-I-1971, Krapovickas 17827 (LP); Ruta Nacional 12, puente sobre el río Corrientes, $25 \mathrm{~km}$ $\mathrm{N}$ de Esquina, 20-II-2020, Gutiérrez et al. 1605 (BA). Depto. Itatí, Ruta Nacional 12, $73 \mathrm{~km}$ E de Corrientes, 21-II-2020, Gutiérrez et al. 1619 (BA). Depto. Ituzaingó, Ituzaingó, 5 km de Ruta Nacional 12, 5-II-1976, Romanczuk 789 (SI). Depto. Paso de los Libres, Parada Pucheta, 22-XII-1946, Huidobro 3857 (LIL). Depto. San Martín, Ruta Provincial 114, $20 \mathrm{~km}$ O de La Cruz, camino a Colonia Pellegrini, 25-II-2020, Gutiérrez et al. 1677 (BA). Depto. San Cosme, Isla Toledo, Río Paraná, 25-VII-1944, Ybarrola s.n. (LIL). Depto. San Miguel, Ruta Provincial 118, 10 km N de San Miguel, 21-II-2020,
Gutiérrez et al. 1628 (BA). Depto. San Roque, Chavarria, cercanías, 28-III-1945, Ybarrola 2786 (LIL). Depto. Santo Tomé, Santo Tomé, 24-II-2020, Gutiérrez et al. 1675 (BA). Entre Ríos. Depto. Federación, Colonia Flores, II-1949, Martínez Crovetto 4986 (SI). Misiones. Depto. Concepción, $8 \mathrm{~km}$ E de Concepción de la Sierra, 24-II-2020, Gutiérrez et al. 1661 (BA). Depto. Eldorado, Puerto de Eldorado, 17-IV-1979, Gómez 91111 (SI).

BRASIL. Rio Grande do Sul. Capão da Canoa, Capão Novo, 7-III-1997, Ribas 1848(MBM); Osório, Trevo entre as rodovias Estrada do Mar e RS030, 18IV-2015, Gonzatti \& Valduga 1769 (ECT).

URUGUAY. Artigas. Margen de la Ruta 3, km 613, 800 m s.m., Arroyo Itacumbú, 13-I-2020 González s.n. (MVM 23485). Salto. Ruta 3, 6 km O de Monteclaro y $12 \mathrm{~km}$ NO de Palomas, 27-II-2020, Gutiérrez et al. 1707 (BA, MVM); Ruta 3, 7 km O de Belén, 27-II-2020, Gutiérrez et al. 1701 (BA, MVM). 

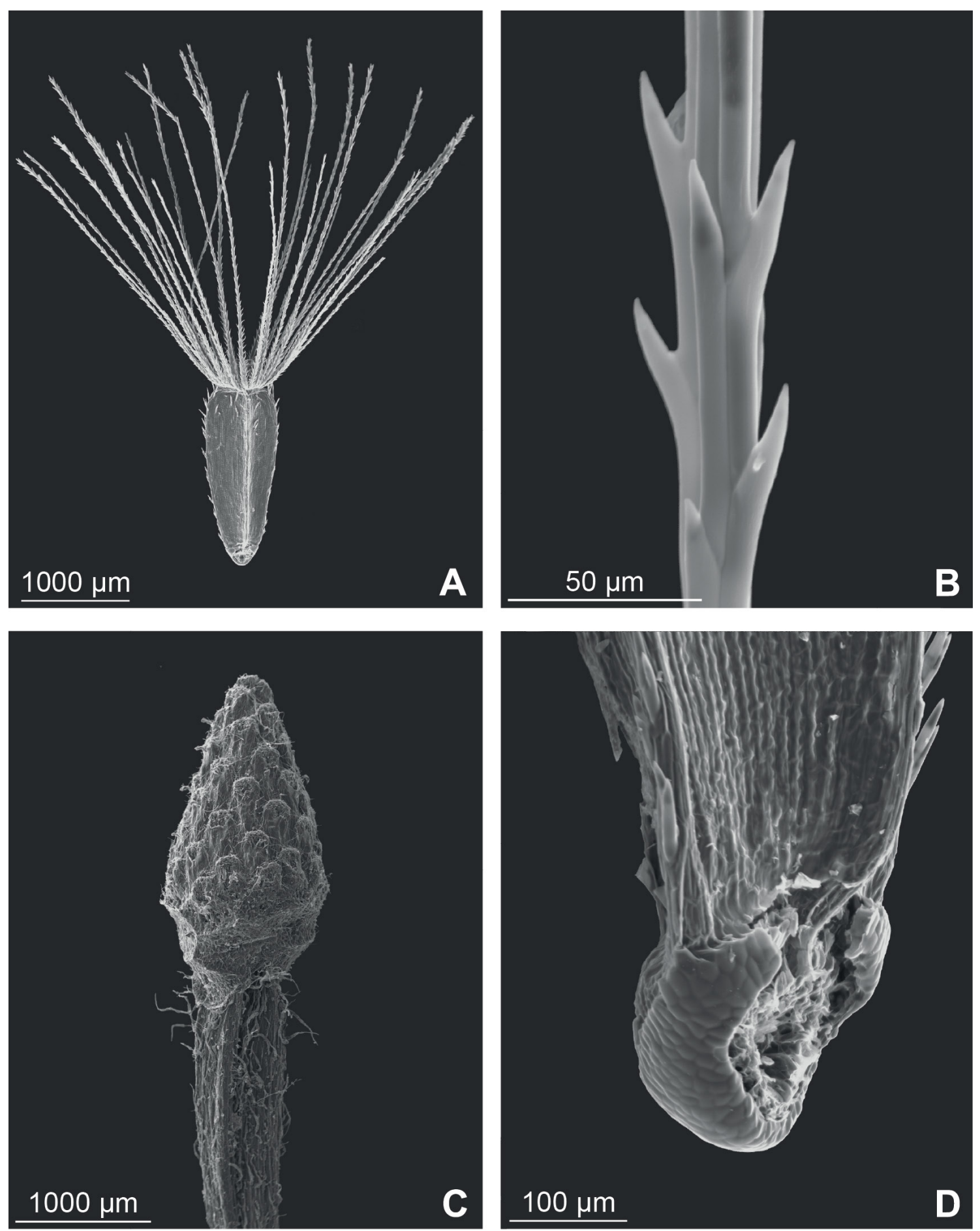

Fig. 4. Reproductive microcharacters in Praxelis. A, bristles of pappus and cypsela. B, part of a scabrid bristle of the pappus. C, conical receptacle and upper part of peduncle. D, lower part of a cypsela showing the asymmetrical carpopodium and lateral insertion of the fruit. Material from Gutierrez et al. 1508 (BA). 


\section{Key to species of Praxelis in Uruguay and surrounding areas of Argentina and Brazil}

1. Solitary capitulum, long pedunculate, or capitula in scapiform terminal branches 2

1. Capitula grouped in corymbiform cymes

\section{3}

2(1). Plants unbranched, hirsute, leaves semi-rosulate, phyllaries pubescent

P. missiona

2. Plants branched, glabrous or glabrescent, leaves opposite, phyllaries glabrous

P. kleinioides

3(1). Herbs up to $0.35 \mathrm{~m}$ tall, laxly pubescent, cymes lax, phyllaries 3-nerved P. ostenii

3. Herbs 0.5-1 m tall, densely pubescent, cymes denses; phylllaries 3-5-nerved

P. clematidea

\section{DISCUSSION AND CONCLUSIONS}

Currently, $P$. clematidea is considered a high risk invader (USDA, 2014). At the end of the $20^{\text {th }}$ century, it was detected as an invasive plant almost simultaneously in Hong Kong and Australia (Corlett \& Shaw, 1995; Waterhouse, 2003). In the past twenty years, it has spread through China and other Asian countries such as Indonesia, Singapore, Taiwan and Thailand (Wang et al., 2006; Wu et al., 2010; Changtragoon et al., 2012; Chen et al., 2018; Tjitrosoedirdjo \& Wahyuni, 2018) and reached North America in southeastern United States of America (Abbott et al., 2008). In general, its presence was detected only after it was well-established, because of its morphological similarity with other weeds of Eupatorieae such as Chromolaena odorata (L.) R.M. King \& H. Rob. and Ageratum conyzoides L. (Waterhouse, 2003; USDA, 2014; Chen et al., 2018). The species has apparently been eradicated in the Republic of Palau, an island located in the western Pacific Ocean, where a few plants were found in isolated patches in 2007 (Space et al., 2008). Even though P. clematidea is often found invading natural environments like woodlands, it shows preference for disturbed areas such as roadsides (Chen et al., 2007; USDA, 2014), similar to the habitats where it was found in northwestern Uruguay and other areas of its original distribution.

With the addition of $P$. clematidea, the tribe Eupatorieae is now represented by 21 genera and 53 species in Uruguay (Rodríguez-Cravero et al., 2019; Flora del Cono Sur, 2020). The absence of this species in the Uruguayan floras of beginnings of the 1900s (Arechavaleta, 1906; Herter, 1930), later studies on the tribe (King \& Robinson, 1987) and regional catalogues or floras (Freire, 2008; Flora del Cono Sur, 2020), in addition to its invasive behavior, might indicate that its presence is relatively recent in the country. However, its Argentinian occurrences near the Uruguayan border and wind dispersed fruit, the absence of a comprehensive flora for the country, and morphological similarities between $P$. clematidea and other species (that caused it to be unnoticed in early stages of invasion all over the World), raises the possibility that it was, until now, overlooked. To date, the available information is not conclusive and phylogeographic studies, for example, could be helpful to understand its evolutionary history in this area.

\section{ACKNOWLEDGEMENTS}

We gratefully acknowledge BA, BAA, ECT, LIL, LP, MBM, MVJB, MVFA, MVM, and SI herbaria. Special thanks to Manuel García† and Meica Valdivia (MVM), Eduardo Marchesi and Mauricio Bonifacino (MVFA), Gonzalo Picasso and his staff (MVJB) for helping with herbarium collections, J. Mauricio Bonifacino and Camilo Pérez (MVFA) with a field trip in Uruguay, Juan F. Rodríguez-Cravero and Agustina Yañez (MACN) with field trips in Argentina and Uruguay, M. Alejandra Migoya with the species illustration (FCAyF-UNLP), Mónica Stampacchio and E. Celeste Alvarenga (BA-MACN) with specimens preparation, and Fabián Tricárico (MACN) with SEM techniques. This work was supported by Consejo Nacional de Investigaciones Científicas y Técnicas (CONICET; PUE 22920160100098CO), Agencia Nacional de Promoción Científica y Tecnológica (PICT-2017-0965) and Universidad Nacional de La Plata (UNLP N814). We also thank two anonymous reviewers for valuable comments on the manuscript. 


\section{BIBLIOGRAPHY}

Abbott, J. R.; C. L. White \& S. B. Davis. 2008. Praxelis clematidea (Asteraceae), a genus and species new for the flora of North America. Journal of the Botanical Research Institute of Texas 2: 621-626. DOI: https://doi.org/10.2307/41971681

Abreu, V. H. R. 2015. Palinologia e taxonomia de espécies de Praxelis Cass. (subtribo Praxelinae, EupatorieaeAsteraceae) ocorrentes no Brasil. PhD diss., Universidade do Estado do Rio de Janeiro. Available at: http://www.bdtd. uerj.br/tde_busca/arquivo.php?codArquivo $=9380$

Abreu, V. H. R. \& R. L. Esteves. 2017. A new species of the Cerrado in Brazil. Phytotaxa 303(1): 77-83. DOI: https:// doi.org/10.11646/phytotaxa.303.1.7

Arechavaleta, J. 1906. Flora Uruguaya; enumeración y descripción breve de las plantas conocidas hasta hoy y de algunas nuevas que nacen espontáneamente y viven en la República Uruguaya. III. Compositae. Anales del Museo Nacional de Montevideo 6: 141-170.

Ávila, F.; V. A. Funk, M. Diazgranados, S. Díaz-Piedrahíta \& O. Vargas. 2016. Praxelis, in R. Bernal, S. R. Gradstein \& M. Celis (eds.), Catálogo de plantas y líquenes de Colombia, v. 1 p. 890. Bogotá: Instituto de Ciencias Naturales, Universidad Nacional de Colombia.

Badillo, V. M. 2001. Lista actualizada de las especies de la familia Compuestas (Asteraceae) de Venezuela. Ernstia 11: 147-215.

Baker, J. G. 1876. Compositae. II. Eupatoriaceae, in C. F. P. Martius \& A. G. Eichler (eds.), Flora Brasiliensis 6: 181374. Lipsiae: Frid. Fleischer.

Barboza, G. E.; J. J. Cantero, C. Nuñez \& L. Ariza Espinar. 2006. Flora medicinal de la provincia de Córdoba (Argentina). Pteridófitas y Antófitas silvestres o naturalizadas. Córdoba: Museo Botánico.

Bernal, R.; S. R. Gradstein \& M. Celis. 2019. Catálogo de plantas y líquenes de Colombia. Bogotá: Instituto de Ciencias Naturales, Universidad Nacional de Colombia. Available at: http://catalogoplantasdecolombia.unal.edu.co

Brazeiro, A. 2015. Eco-regiones de Uruguay: biodiversidad, presiones y conservación: aportes a la Estrategia Nacional de Biodiversidad. Facultad de Ciencias, CIEDUR, VSUruguay, SZU. Montevideo: Tradinco SA.

Cabrera, A. L. 1941. Compuestas bonaerenses. Revisión de las compuestas de la Provincia de Buenos Aires, la Capital Federal y la Isla Martín García. Revista del Museo de La Plata 4: 1-450.

Cabrera, A. L. 1963. Compositae, in A. L. Cabrera (ed.), Flora de la Provincia de Buenos Aires. Colecciones Cientificas del Instituto Nacional de Tecnología Agropecuaria 4 (6a): 1-443.
Cabrera, A. L. \& N. Vittet. 1954. Catálogo de las Eupatorieas argentinas. (Compositae). Revista del Museo de La Plata 8: 179-263.

Cabrera, A. L.; W. C. Holmes \& S. McDaniel. 1996. Compositae III, in R. Spicchiger \& L. Ramella (eds.), Flora del Paraguay 25, pp. 1-349. Geneva: Conservatoire et Jardín Botaniques de la Ville de Geneve-Missouri Botanical Garden.

Cabrera, A. L.; J. C. Crisci, G. Delucchi, S.E. Freire, D. A. Giuliano, L. Iharlegui, L. Katinas, A. A. Sáenz, G. Sancho \& E. Urtubey. 1999. Catálogo ilustrado de las Compuestas (= Asteraceae) de la Provincia de Buenos Aires, Argentina: sistemática, ecología y usos. La Plata: Secretaría de Política Ambiental, Provincia de Buenos Aires.

Candolle, A. P. de. 1836. Eupatorium, in Prodromus Systematis Naturalis Regni Vegetabilis, vol. 5, pp. 141-186. Parisiis: Treuttel \& Würtz.

Cantero, J. J.; C. O. Núñez, G. Bernardello, A. Amuchástegui, J. Mulko, P. Brandolín, M. V. Palchetti, J. Iparraguirre, N. Virginil \& L. Ariza Espinar. 2019. Las plantas de importancia económica en Argentina, $1^{\circ}$ ed. Río Cuarto: UniRíoEditora.

Changtragoon, S.; P. Ongprasert, S. Tangmitcharoen, S. Diloksampan, V Luangviriyasaeng, P. Sornsathapornkul \& S. Pattanakiat. 2012. Country Report on Forest Genetic Resources of Thailand. The state of the world's forest genetic resources. Bangkok: Department of National Parks, Wildlife and Plant Conservation, Bangkok, Thailand p. 128.

Chen, L. M. J.; B. C. Ho, L. M. Choo \& S. L. Koh. 2018. Additions to the Flora of Singapore, new and overlooked records of naturalized plant species (1). Gardens' Bulletin Singapore 70: 91-101. DOI: https://doi.org/10.26492/gbs70(1).2018-09

Chen, W.; G. Y. Lan, F. An, J. S. Jiang, Z. H, Wang, Q. B. Chen \& X. M. Wu. 2007. Niche characteristics of Eupatorium catarium community in Hainan. Journal-Northwest Forestry University 22: 24-27.

Christ, A. L. \& M. R. Ritter. 2019. A taxonomic study of Praxelinae (Asteraceae-Eupatorieae) in Rio Grande do Sul, Brazil. Phytotaxa 393: 141-197. DOI: https://doi. org/10.11646/phytotaxa.393.2.5

Corlett, R. T. \& J. C. Shaw. 1995. Praxelis clematidea: yesterday South America, today Hong Kong, tomorrow the world? Memoirs of the Hong Kong Natural History Society 20: 235-236.

De Egea, J.; F. Mereles, M. del C. Peña-Chocarro \& G. Céspedes, 2016. Checklist for the crop weeds of Paraguay. PhytoKeys, 73: 13-92. DOI: https://doi.org/110.3897/phytokeys.73.10135

Dillon, M. O. \& N. Hensold. 1993. Asteraceae, in L. Brako \& J. L. Zarucchi (eds.), Catalogue of the Flowering Plants and Gymnosperms of Peru. Monographs in Systematic Botany from the Missouri Botanical Garden 45: 103-189. 
eFloras. 2020. Published on the Internet http://www.efloras.org [accessed 22 July 2020]. Missouri Botanical Garden, St. Louis, MO \& Harvard University Herbaria, Cambridge, MA. Available at http://www.efloras.org/florataxon.aspx?flora id=2\&taxon_id=242341266

Falcão, H.; G. L. A. Maia, F. Bonamin, H. Kushima, T. M. Moraes, C. A. H. Lima, C. Takayama, A. L. Ferreira, A. R. M. Souza Brito, M. de F. Agra, J. M. Barbosa Filho \& L. M. Batista. 2013. Gastroprotective mechanisms of the chloroform and ethyl acetate phases of Praxelis clematidea (Griseb.) R. M. King \& H. Robinson (Asteraceae). Journal of Natural Medicines 67: 480-491. DOI: https://doi. org/10.1007/s11418-012-0705-4

Filho, A. O.; H. M. B Fernandes, J. P. Sousa, G. L. A. Maia, J. M. Barbosa-Filho, E. O. Lima \& T. L. Oliveira. 2013. Antibacterial activity of flavonoid 5.7. 4'-trimethoxyflavone isolated from Praxelis clematidea R. M. King \& Robinson. Boletín Latinoamericano $y$ del Caribe de Plantas Medicinales y Aromáticas 12: 400-404.

Filho, A. O.; H. M. B Fernandes, J. P. Sousa, D. R. P. Meireles, G. L. A. Maia, G. L. Filho, J. P. de Siqueira Júnior \& E. O. Lima. 2016. In vitro anti-Candida activity and mechanism of action of the flavonoid isolated from Praxelis clematidea against Candida albicans species. Journal of Applied Pharmaceutical Science 6: 66-69. DOI: https://doi. org/10.7324/JAPS.2016.600111

Flora del Cono Sur [permanently updated, accessed 2020]. Catálogo de las Plantas Vasculares del Conosur, Instituto de Botánica Darwinion. Available at: http://www.darwin.edu. ar/proyectos/floraargentina/fa.htm

Freire, S. E. 2008. Eupatorium, in F. O. Zuloaga, O. Morrone \& M. J. Belgrano (eds.), Catálogo de las Plantas Vasculares del Cono Sur: (Argentina, Sur de Brasil, Chile, Paraguay y Uruguay). Monographs in Systematic Botany from the Missouri Botanical Garden 107: 1277-1303.

Freire, S. E. \& L. Ariza Espinar. 2014. Praxelis Cass., in F. O Zuloaga, M. J. Belgrano \& A. M. Anton (eds.), Flora Argentina, Flora Vascular de la República Argentina, Dicotyledoneae, Asteraceae vol. 7 (1), 403-406. Buenos Aires: Estudio Sigma SRL.

Fu, W.; K. Huang, H. H. Cai, J. Li, D. L. Zhai, Z. C. Dai, \& D. L. Du. 2017. Exploring the potential of naturalized plants for phytoremediation of heavy metal contamination. International Journal of Environmental Research 11: 515521. DOI: https://doi.org/10.1007/s41742-017-0045-z

Funk, V. A.; T. Hollowell, P. Berry, C. Kelloff \& S. N. Alexander. 2007. Checklist of the plants of the Guiana Shield (Venezuela: Amazonas, Bolivar, Delta Amacuro; Guyana, Surinam, French Guiana). Contributions from the United States National Herbarium 55: 1-584.
Gonzáles, P.; A. Cano \& H. Robinson. 2018. A new genus of Compositae (Eupatorieae, Piqueriinae) from Peru, named Centenaria to honour the $100^{\text {th }}$ anniversary of the Natural History Museum of the National University Mayor of San Marcos. PhytoKeys 113: 69-77. DOI: https://doi. org/10.3897/phytokeys.113.28242

Grossi, M. A.; J. N. Viera Barreto, A. Plos, J. F. RodríguezCravero, N. B. Forte, D. G. Gutiérrez \& G. Sancho. 2020. Providing tools for the reassessment of Eupatorieae (Asteraceae): comparative and statistical analysis of reproductive characters in South American taxa. Perspectives in Plant Ecology, Evolution and Systematics; forthcoming. DOI: https://doi.org/10.1016/j.ppees.2020.125566

Herter, G. 1930. Estudios Botánicos en la Región Uruguaya. IV. Florula Uruguayensis, plantae vasculares. Montevideo: Sumptibus rei publicae.

Hind, D. J. N. \& H. Robinson. 2007. Eupatorieae, in K. Kubitzki (ed.), The Families and Genera of Vascular Plants 8: pp. 510-574. Berlin: Springer.

Hurrell, J. A. 2013. Flora Rioplatense: sistemática, ecología y etnobotánica de las plantas vasculares rioplatenses. II. Dicotiledóneas. 7a: Asteraceae. Corrientes: Sociedad Argentina de Botánica.

King, R. M. \& H. Robinson. 1987. The genera of the Eupatorieae (Asteraceae). Monographs in Systematic Botany from the Missouri Botanical Garden 22: 1-581. DOI: https://doi. org/10.5962/bhl.title.156613

Li, S.; Y. Chen \& Q. Wang. 2017. Antibacterial activity of extracts on invasive plant of Praxelis clematidea (Griseb.) R. M. King \& H. Rob. and Ageratum conyzoides L. Journal of Nuclear Agricultural Sciences 31: 1717-1722.

Marzocca, A. 1976. Manual de malezas, $3^{\circ}$ ed. Buenos Aires: Hemisferio Sur.

Novara, L. J. 2009. Tribu 2. Eupatorieae Cass, in L. J. Novara (ed.), Flora del Valle de Lerma (Provincia de Salta, República Argentina). Aportes Botánicos de Salta, Serie Flora 9(2): 1-168.

Panero, J. L. \& B. S. Crozier. 2016. Macroevolutionary dynamics in the early diversification of Asteraceae. Molecular Phylogenetics and Evolution 99: 116-132. DOI: https://doi.org/10.1016/j.ympev.2016.03.007

Pérez Sobrino, C. 2016. Revisión taxonómica de Grazielia R. M. King \& H. Rob., Asteraceae (Eupatorieae) en Uruguay. Licentiate thesis. Universidad de la República.

Rivera, V. L.; J. L. Panero, E. E. Schilling, B. S. Crozier \& M. D. Moraes. 2016a. Origins and recent radiation of Brazilian Eupatorieae (Asteraceae) in the eastern Cerrado and Atlantic Forest. Molecular Phylogenetics and Evolution 97: 90-100. DOI: https://doi.org/10.1016/j.ympev.2015.11.013 
Rivera, V. L.; S. Da Costa Ferreira \& J. L. Panero. 2016b. Trichogoniinae, a new subtribe of Eupatorieae (Asteraceae). Phytotaxa 260: 296-300. DOI: https://doi.org/10.11646/ phytotaxa.260.3.10

Robinson, B. L. 1923. Records preliminary to a general treatment of the Eupatorieae, III. Contributions from the Gray Herbarium of Harvard University 68: 3-43.

Robinson, H. 2014. Praxelis, in P. M. Jørgensen, M. H. Nee \& S. G. Beck (eds.), Catálogo de las plantas vasculares de Bolivia. Monographs in Systematic Botany from the Missouri Botanical Garden 127: 357-358.

Robinson, H.; E. Schilling \& J. L. Panero. 2009. Eupatorieae, in V. A. Funk, A. Susanna, T. F. Stuessy \& R. J. Bayer (eds.), Systematics, Evolution and Biogeography of Compositae, pp. 731-744. Viena: IAPT.

Rodríguez-Cravero, J. F.; D. G. Gutiérrez \& L. Katinas. 2017. Lectotypifications in Uruguayan Stevia (Asteraceae, Eupatorieae). Phytotaxa 291: 116-122. DOI: https://doi. org/10.11646/phytotaxa.291.2.2

Rodríguez-Cravero, J. F.; D. G. Gutiérrez, L. Katinas, M. A. Grossi, J. M. Bonifacino \& E. Marchesi. 2019. A revision and morphological analysis of the Uruguayan species of Stevia (Compositae, Eupatorieae). Rodriguésia 70: e01532018. DOI: https://doi.org/10.1590/2175-7860201970078

Roque, N.; S. C. Ferreira \& C. van der Berg. 2017. Lapidia, a new monotypic genus of Asteraceae (Eupatorieae) from Brazil, and its phylogenetic placement. Phytotaxa 291: 1-16. DOI: https://doi.org/10.11646/phytotaxa.291.1.1

Sancho, G.; J. M. Bonifacino \& J. F Pruski. 2006. Revision of Microgyne (Asteraceae: Astereae), the correct name for Microgynella. Systematic Botany 31: 851-861. DOI: https:// doi.org/10.1600/036364406779695843

Space, J. C.; D. H. Lorence \& A. M. LaRosa. 2008. Report to the Republic of Palau: 2008 update on invasive plant species. U.S.D.A. Forest Service, Hilo, Hawai`i, USA.

Thiers, B. [permanently updated, accessed 2020]: Index Herbariorum: a global directory of public herbaria and associated staff; New York Garden's Virtual Herbarium. Available at: http://sweetgum.nybg.org/science/ih/

Tjitrosoedirdjo, S. S. \& I. Wahyuni. 2018. Rekor baru keberadaan Praxelis clematidea (Asteraceae) di Indonesia. Prosiding Seminar Nasional XX Himpunan Ilmu Gulma Indonesia: Resistensi Gulma Terhadap Herbisida dan Dampaknya terhadap Lingkungan dan Produk Pertanian: 212-217.
Troncoso Oliveira, C. 2010. Praxelis, in R. C. Forzza, J. F. A. Baumgratz, C. E. M. Bicudo, A. A. Carvalho Jr., A. Costa, D. P. Costa, M. Hopkins, P. M. Leitman, L. G. Lohmann, L. C. Maia, G. Martinelli, M. Menezes, M. P. Morim, M. A. N Coelho, A. L. Peixoto, J. R. Pirani, J. Prado, L.P. Queiroz, V. C. Souza, J. R Stehmann, L. S. Sylvestre, B. M. T Walter \& D. Zappi (eds.), Catálogo de plantas e fungos do Brasil, v.1, pp. 733. Rio de Janeiro: Instituto de Pesquisas Jardim Botânico do Rio de Janeiro.

Trujillo, C.; L. Katinas \& J. M. Bonifacino. 2014. El género Panphalea (Compositae: Nassauvieae) en Uruguay. Boletín de la Sociedad Argentina de Botánica 49: 93-105. DOI: https://doi.org/10.31055/1851.2372.v49.n1.7828

USDA. 2014. Weed Risk Assessment for Praxelis clematidea R. M. King \& H. Rob. (Asteraceae) - Praxelis. United States Department of Agriculture, Animal and Plant Health Inspection Service, version 2. Available at: https://www. aphis.usda.gov/aphis/ourfocus/planthealth/plant-pest-anddisease-programs

Valtierra, V. \& J. M. Bonifacino. 2014. Revisión taxonómica de Baccharis sect. Heterothalamus (Asteraceae: Astereae) en Uruguay. Boletín de la Sociedad Argentina de Botánica 49: 613-620. DOI: https://doi.org/10.31055/1851.2372.v49. n4.9993

Wang, Z.; F. An \& Q. B. Chen. 2006. Praxelis (Praxelis clematidea): a new invasive exotic weed in China. Chinese Journal of Tropical Agriculture 6: 33-37.

Waterhouse, B. M. 2003. Know your enemy: recent records of potentially serious weeds in northern Australia, Papua New Guinea and Papua (Indonesia). Telopea 10: 477-485. DOI: https://doi.org/10.7751/telopea20035624

Wei, H.; M. Huang, G. Quan, J. Zhang, Z. Liu, \& R. Ma. 2018. Turn bane into a boon: Application of invasive plant species to remedy soil cadmium contamination. Chemosphere 210: 10131020. DOI: https://doi.org/10.1016/j.chemosphere.2018.07.129

Wu, S. H.; T. A Yang, Y. C. Teng, C. Y. Chang, K. C. Yang \& C. F. Hsieh. 2010. Insights of the latest naturalized flora of Taiwan: change in the past eight years. Taiwania 55: 139-159.

Xiao, L.; Y. Huang, Y. Wang, J. Xu \& X. He. 2020. Antineuro inflammatory benzofurans and lignans from Praxelis clematidea. Fitoterapia 140: 1-9. DOI: https://doi. org/10.1016/j.fitote.2019.104440

Zarlavsky, G. E. 2014. Histología vegetal: técnicas simples y complejas. Buenos Aires: Sociedad Argentina de Botánica. 